\title{
AN ALTERNATIVE EXPLANATION FOR THE ALLEGED 'IMPERATIVAL' PARTICIPLES OF ROMANS 12:9-21
}

\author{
Jeffrey S. Lamp
}

\begin{abstract}
Summary
The participles of Romans 12:9-21 have occasioned much discussion among grammarians and commentators. The primary debate concerns whether the participles are functioning imperativally or whether they might be connected with a finite verb in the context of the passage. This article suggests that the participles might indeed be connected with a finite verb, but one that is unexpressed in the passage.
\end{abstract}

\section{Introduction}

The participles of Romans 12:9-21 have fostered much discussion concerning their function. Many recent commentaries on Romans have concluded that the participles are functioning imperativally, and virtually all English translations render them in this way. This paper will re-examine the function of these so-called 'imperatival participles', with the dictum of A. T. Robertson in view: 'In general it may be said that no participle should be explained this way [imperativally] that can properly be connected with a finite verb.' ${ }^{1}$ Robertson himself concluded that the participles in Romans 12:9-21 could not be connected with any verb in the context and thus function imperativally. The present discussion will suggest that the participles are indeed contextually dependent on another verb, but one that is unexpressed in the passage: the imperative copula.

1 A. T. Robertson, A Grammar of the Greek New Testament in the Light of Historical Research (Nashville: Broadman, 1934): 1133-34. 
This discussion will first list the proposed solutions for the usage of the participles in Romans 12:9-21. ${ }^{2}$ The present proposal will then be stated, followed by several considerations in support of the proposal.

\section{Previous Solutions}

These participles are explained in one of two general ways. ${ }^{3}$ One position sees them as dependent on some finite verb in the context. ${ }^{4}$ Differences between solutions in this position centre on the identification of the verb upon which the participles are dependent. The other frequently advanced position is that the participles are 'imperatival'. Some with this position argue that the NT usage is shaped by Semitic influence, ${ }^{5}$ while others suggest that the NT usage is a natural development in the Greek language itself. ${ }^{6}$

\section{An Alternative Proposal}

The argument of the present discussion is that the participles in Romans 12:9-21 that are typically labelled 'imperatival' are connected

2 As such, other suggested instances of the imperatival participle in the NT fall beyond the scope of the present discussion.

3 See S. E. Porter, Verbal Aspect in the Greek New Testament, with Reference to Tense and Mood (New York: Peter Lang, 1989): 370-77, for a detailed discussion.

4 E.g. E. Mayser, Grammatik der griechischen Papyri aus der Ptolemäerzeit (Berlin: de Gruyter, 1906-34): 1:196-97 n. 3, 340-41; K. L. McKay, A New Syntax of the Verb in New Testament Greek: An Aspectual Approach (New York: Peter Lang, 1994): 84; N. T. Wright, Romans (NIB; Nashville: Abingdon, 2002): 711.

5 E.g. C. K. Barrett, 'The Imperatival Participle', ExpTim 59 (1948): 165-66; D. A. Black, 'The Pauline Love Command: Structure, Style, and Ethics in Romans 12.9-21', FN 1 (1989): 3-21; M. Black, Romans (NCB; Grand Rapids: Eerdmans, 1973): 172; D. Daube, The New Testament and Rabbinic Judaism (New York: Arno, 1973): 90-102; J. D. G. Dunn, Romans 9-16 (WBC; Dallas: Word, 1988): 737-38; B. Fanning, Verbal Aspect in New Testament Greek (Oxford: Clarendon, 1990): 387-88; P. Kanjuparambil, 'Imperatival Participles in Rom. 12:9-21', JBL 102 (1983): 285-88; N. Turner, Grammatical Insights into the New Testament (Edinburgh: T\&T Clark, 1965): 165-68.

6 E.g. BDF, 245-46; J. Fitzmyer, Romans (AB; New York: Doubleday, 1993): 65253; H. G. Meecham, 'The Use of the Participle for the Imperative in the New Testament', ExpTim 58 (1947): 207-208; D. Moo, The Epistle to the Romans (NICNT; Grand Rapids: Eerdmans, 1996): 776 n. 27; J. H. Moulton, Prolegomena, vol. 1 of $A$ Grammar of New Testament Greek (3rd edn; Edinburgh: T\&T Clark, 1906): 180-83; A. P. Salom, 'The Imperatival Use of the Participle in the New Testament', Australian Biblical Review 11 (1963): 41-49; M. Zerwick, Biblical Greek Illustrated from Examples (Rome: Scripta Pontificii Instituti Biblici, 1963): 129-30. 
with a finite verb, namely, the unexpressed imperative form of the copula. ${ }^{7}$ As such, the best way to classify the function of these participles is as predicates of the unexpressed verb. This proposal is not novel; Sanday and Headlam proffered a similar explanation for these participles over a century ago, though without supporting argumentation. ${ }^{8}$ The following discussion will identify several considerations in support of this proposal.

\subsection{Imperatival Context}

The passage is clearly exhortative and is thus appropriately expressed in an imperatival sense. However one understands the participles, there are nine occurrences of imperative mood verbs in the passage. Virtually all proposed solutions agree that the participles occur in a context where the sense could have been communicated with an imperative mood verb. So the real issue at hand is to explain how the imperatival sense was communicated using the participles. While other proposals are certainly plausible explanations to account for this imperatival sense, it may be best to construe the participles as predicates of the unexpressed imperative copula, particularly if it were shown that Paul had prepared his audience for this possibility.

\subsection{The Opening Sentence of the Passage (v. 9)}

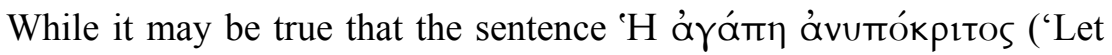
love be without hypocrisy') serves as the topic of the entire passage, it is arguable that it functions as a command or exhortation as well. ${ }^{9}$ This

7 Moulton (Prolegomena, 180) notes that the absence of the obviously necessary imperative copula ('ُఠтદ', 'be') with the participles/adjectives of Rom. 12:9-21 argues for taking these participles as imperatival. The present discussion agrees with Moulton that the copula is necessary, but that its absence need not lead to the conclusion that the participles must be functioning imperativally.

8 W. Sanday and A. C. Headlam, A Critical and Exegetical Commentary on the Epistle to the Romans (ICC; Edinburgh: T\&T Clark, 1902): 360. Turner (Syntax, vol. 3 of A Grammar of New Testament Greek, by J. H. Moulton [Edinburgh: T\&T Clark, 1963]: 343), while noting that the imperatival participle is well known in Koine as well

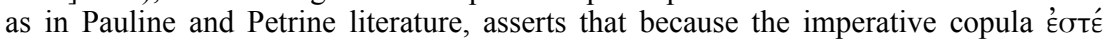
('be') does not occur in the NT we must presume it as understood with the participles in this passage. Later Turner, discussing the apparent use of participles for the imperative in 1 Pet. $(1: 14,22 ; 2: 18 ; 3: 1,7,8 ; 4: 8)$, suggests that the participles may 'be part of a periphrastic construction, with be (imperative) in ellipse'. He also suggests it may be a Hebraism. See Style, vol. 4 of A Grammar of New Testament Greek, by J. H. Moulton (Edinburgh: T\&T Clark, 1976): 128. Turner provides a more detailed discussion of possible Hebraic influence in Grammatical Insights, 165-68.

9 So Moo, Romans, 774-75. 
is how virtually all English translations render the sentence. With the adjective ávumókpıtos in the predicate position, the implied verb would then be the third person singular imperative form of the copula. ${ }^{10}$ The effect of this observation on the present argument is twofold. First, it is a construction in which the copula is implied rather than explicitly stated. Secondly, in context, the mood of this unexpressed verb is imperative. ${ }^{11}$ So the construction of this sentence may suggest that the following participial clauses are so understood.

\subsection{Construction of the Participles in vv. 10-13a}

In verses $10-13 a$ there are seven participles found in the construction articular dative noun (some with modifiers) plus plural nominative participle. The first six of these articular dative nouns are singular with the last in the sequence being plural. However, in verse 10, the first in the sequence of these participial constructions is sandwiched between two occurrences of a parallel construction: singular articular dative noun (one with a modifier) plus plural nominative adjective. In these constructions the adjective functions as the predicate adjective of an unexpressed copula, contextually best understood in the imperative mood. ${ }^{12}$ Given that it is quite easy to understand the construction with the adjectives, it is reasonable to suggest that the participial constructions be understood in the same way.

\subsection{Imperative of a Copula in verse 16}

The occurrence of the imperative form Yiveo $\theta \varepsilon$ ('be') in verse 16 may provide a clue to the interpretation of the unusual use of the participles in the passage. This copula appears with an adjective and may confirm the earlier observation on the parallel constructions in verses 10-13a,

10 Two witnesses, Clement of Alexandria and 131, offer as a textual variant the

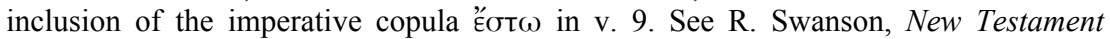
Greek Manuscripts: Romans (Wheaton: Tyndale House, 2001): 193.

11 R. Jewett (Romans [Hermeneia; Minneapolis: Fortress, 2007]: 759-60) similarly argues that an unexpressed copula in this sentence lends its modal force to the participles in vv. 9-21, but that this copula should be the indicative form Éotıv ('is'). The result is that the participles are understood as part of present periphrastic constructions with an unexpressed copula (see his translation on p. 755). The imperatival context of the passage suggests that the imperative mood is a more natural modal fit for the unexpressed copula.

12 Fanning (Verbal Aspect, 386 n. 81) suggests that the form of the copula that might be in ellipse is an adverbial participial form of the copula. He provides no explicit support for this conjecture, perhaps because he finally argues that the participles in this passage are independent imperatival participles (387). 
namely, that the adjectives in the earlier portion of the passage are predicate adjectives of an unexpressed copula in the imperative mood, thus suggesting a similar understanding of the participles there.

\subsection{Stylistic Presentation of verses 10-13a}

As noted above, the participles in verses 10-13a appear to have a carefully constructed form. The lack of the copula may have been due to a perceived inelegance were it to appear in such a stylised presentation. Or perhaps the absence of the copula may lie in the suggestion that Paul is making use of mitigated commands, softening what might be perceived as the harshness of repeating imperatives. ${ }^{13}$ This does not preclude that the participles are functioning imperativally, but it may explain the absence of the copula in terms of the present proposal.

\section{6 'Imperatival' Infinitives in verse 15}

Grammarians note that this use of the infinitive, though rare in the NT, is found as early as Homer and is well attested in Hellenistic Greek. ${ }^{14}$ The presence of these independent and possibly 'imperatival' infinitives in this passage may suggest that a similar usage is in view with the use of the participles. However, it may be possible that these infinitives are not truly imperatival, but are rather elliptical, best understood by supplying a governing verb of necessity, such as $\delta \varepsilon \tilde{i}$ ('it is necessary'). ${ }^{15}$ So it may be that the participles are behaving similarly by omission of the imperatival copula.

\subsection{Pragmatics}

As noted earlier, the independent participle is an acceptable use of the participle in Greek. The true issue in discussing the topic of independent participles is not the question of why the participles appear where modal verbs might be expected, but rather what is the implied or stated headterm with which the participle forms its grammatical relationship. ${ }^{16}$ Given that the context of Romans 12:9-21 is exhortative and that the participles are plural in number, the implied headterm

13 Cf. N. F. Miller, 'The Imperativals of Romans 12' in Linguistics and New Testament Interpretation: Essays on Discourse Analysis, ed. D. A. Black (Nashville: Broadman, 1992): 173-74.

14 Porter, Verbal Aspect, 377; D. Wallace, Greek Grammar beyond the Basics (Grand Rapids: Zondervan, 1996): 608.

15 BDF, 196.

16 Porter, Verbal Aspect, 375. 
would be the second person plural pronoun. While this might simply be inferred from the context from the imperative mood verbs in the passage, the current proposal would place the implied headterm in the more conceptually immediate proximity of the participle via introduction of an implied copula.

\subsection{Similarity of Construction in Mishnaic Hebrew}

Contact with Hellenistic Greek forced Mishnaic Hebrew to respond to an aspectual deficiency in the verbal system that limited expression of the imperfective aspect in the imperative. The response was a marked increase in a construction in which the imperative copula precedes an adjective. ${ }^{17}$ This consideration neither explains Paul's usage, nor does it see Paul's use as a direct influence behind this feature of Mishnaic Hebrew. But it does show that the construction imperative copula plus adjective would be at home in the context of a Jewish writer of Greek such as Paul. The usage in Romans 12:9-21 would be an elliptical modification of this pattern.

\section{Conclusion}

In the final analysis, it may be that the participles of Romans 12:9-21 are indeed imperatival participles. However, perhaps a consideration more in line with Paul's pastoral concern in the passage may elucidate a potential benefit of the current proposal. It would shift the imperatival force in the clauses from the participles to the implied copula, thus leaving the participles to function in a more robust adjectival sense by predicating a quality in terms of a verbal action to the subject. It allows the participles to be construed in a way that is semantically quite common for participles while maintaining the sense of exhortation found in the passage.

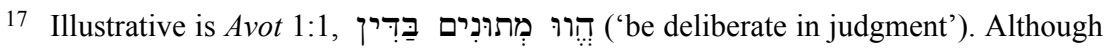
מִתרנִים ('deliberate') is listed lexically as an adjective, is in form a Qal passive participle. Were this clause translated into Greek, בכּדּרִ ('in judgment') would be rendered with an articular dative case construction, which occurs repeatedly in Rom. 12:10-13a. I thank Randall Buth for bringing this to my attention. 